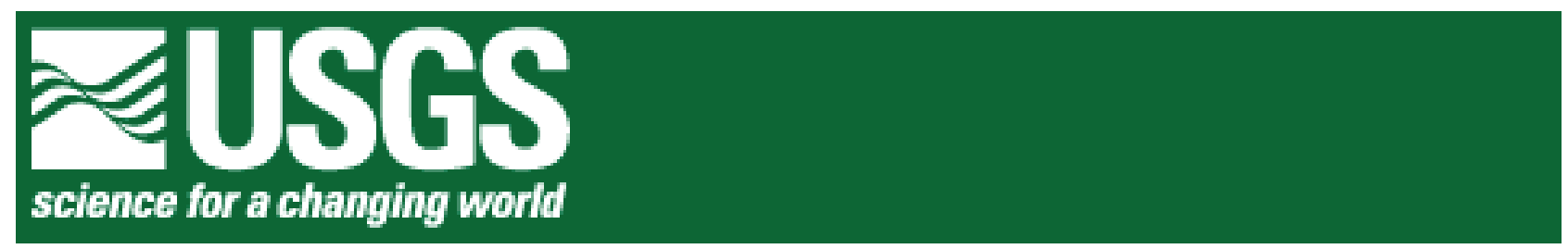

\title{
Hydrogeologic Investigations by the U.S. Geological Survey at the Former Fort Benjamin Harrison, Marion County, Indiana
}

\section{Background}

As part of the U.S. Department of Defense Base Realignment and Closure process, the former Fort Benjamin Harrison in Marion County, Indiana (called "Fort Harrison" in this fact sheet), was placed on the Base Closure List in 1991. Property disposal and reuse activities began when Fort Harrison was decommissioned in 1995; work continues through 1999.

Fort Harrison was located on approximately 2,500 acres about 10 miles northeast of downtown Indianapolis, Ind., in the City of Lawrence (fig. 1). Since 1903, the installation served as a major training facility that at times included schools, a hospital, and Army Finance and Soldier Support Centers.

In 1996, the Army leased 1,700 acres of woodland and recreational facilities to the Indiana Department of Natural Resources as Fort Harrison State Park. Another 550 acres became privately owned for industrial, commercial, and residential purposes.

\section{Hydrogeologic Investigations}

During base closure, the Army initiated an evaluation of about 36 individual sites at Fort Harrison for compliance with Federal and State environmental requirements. The U.S. Geological Survey (USGS) provided technical assistance to the Army through hydrogeologic investigations that examined:

- ground-water quality and groundwater flow at two closed landfills;

- surface-water/ground-water interaction near one closed landfill;

- hydrogeologic mapping of the thickness and horizontal extent of glacial aquifers throughout Fort Harrison; and

- ground-water age in these aquifers.

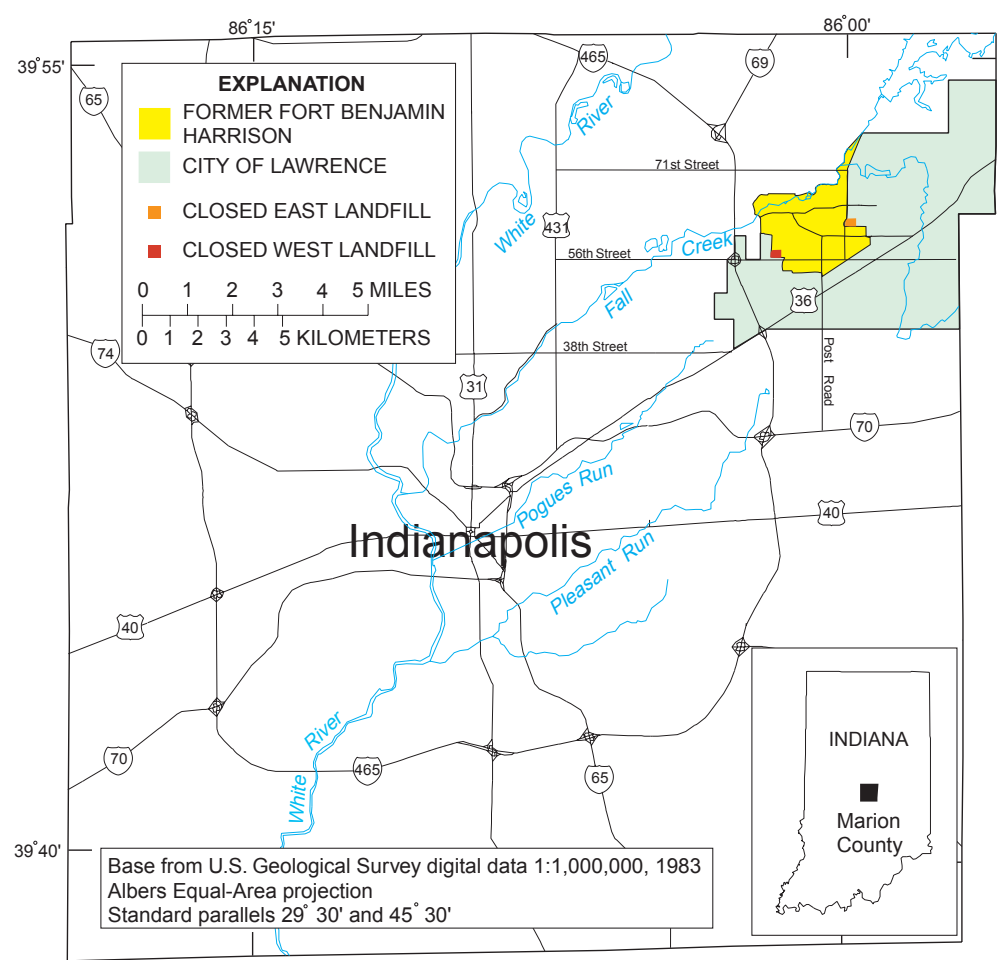

Figure 1. Location of the former Fort Benjamin Harrison, Marion County, Indiana.

\section{Water-Quality at Two Closed Landfills}

The 29-acre east landfill (fig. 1) was used by the Army for less than 10 years during the 1950's and 1960's and was closed in 1971. Property that included the closed east landfill was deeded to the City of Lawrence in 1974 and is currently part of a park with baseball fields.

In response to uncertainty among area residents about water quality near the landfill, the Army requested the USGS investigation in 1997 during the closure of Fort Harrison. For the study, groups of new monitoring wells were screened at several depths around the landfill boundary. Two sets of water-quality data from these wells indicated the landfill was not having an adverse effect on streams or aquifers in the area.

The Army operated the west landfill (fig. 1) for about 50 years until 1991; closure activities were completed in 1994.
The USGS provided monitoring of water quality and ground-water flow from 1995 through 1997. Water from natural springs along a streambank below the landfill were sampled as part of the monitoring. The analytical data indicated water quality at the springs was similar to that in monitoring wells downgradient from the closed west landfill and that the springs were hydraulically connected with the aquifer below the landfill. These findings led to an additional study by the USGS of the interaction of surface water and ground water near the west landfill.

\section{Surface-Water/Ground-Water Interaction}

During 1996, the USGS collected the following hydrologic data near the closed west landfill: precipitation, evaporation, ground-water levels, streamflow, flow at springs, soil permeability and infiltration, and hydraulic conductivity. 
Quick responses of ground-water levels to precipitation indicated infiltration through fractures and macropores because permeability and infiltration were slow through the soil cover and clay cap on the landfill. Flow from the natural springs and streamflow were affected by precipitation and evaporation. Flow from the springs contributed very little to streamflow.

\section{Hydrogeologic Mapping}

Previous site-specific studies initiated by the Army provided data from numerous monitoring wells completed in the upper 30 feet of glacial sediments at Fort Harrison. Deeper hydrogeology had not been mapped because too few wells had been installed to greater depths. The USGS investigation in 1998 broadly defined the thickness and horizontal extent of aquifers within the glacial sediments at Fort Harrison and described horizontal and vertical ground-water flow.

For the hydrogeologic mapping, nearly continuous cores of sediment were described at new, deep boreholes. New monitoring wells were constructed, and geophysical logs were made in the deep wells. The new data were combined with information from previous investigations at Fort Harrison.

In a conceptual model of the hydrogeology (fig. 2), the glacial sediments are vertically divided into shallow, middle, and deep till units. Layers consisting predominantly of sand or sand and gravel are the aquifers within the glacial till that is mostly silty, sandy clay. Corresponding to the shallow, middle, and deep till units were the shallow, middle, and deep (called "Fall Creek") aquifers.

The shallow aquifer consists of vertically and horizontally discontinuous layers. The middle aquifer, mapped as continuous in the eastern part of Fort Harrison, was found to be thickest near the central part and thinnest toward the east. Geologic logs indicated that the middle aquifer was discontinuous between the central and western parts of Fort Harrison, although a thick section of the aquifer also was mapped near the western boundary. The Fall Creek aquifer was found to be as thick as 15 feet; however, only two wells penetrated this aquifer. No data were obtained for the Fall Creek aquifer in the west, south, or central parts of Fort Harrison.

Data from the two synoptic water-level measurements indicated the predominant direction of horizontal ground-water flow in the shallow and middle till units beneath the southeastern part of Fort Harrison was

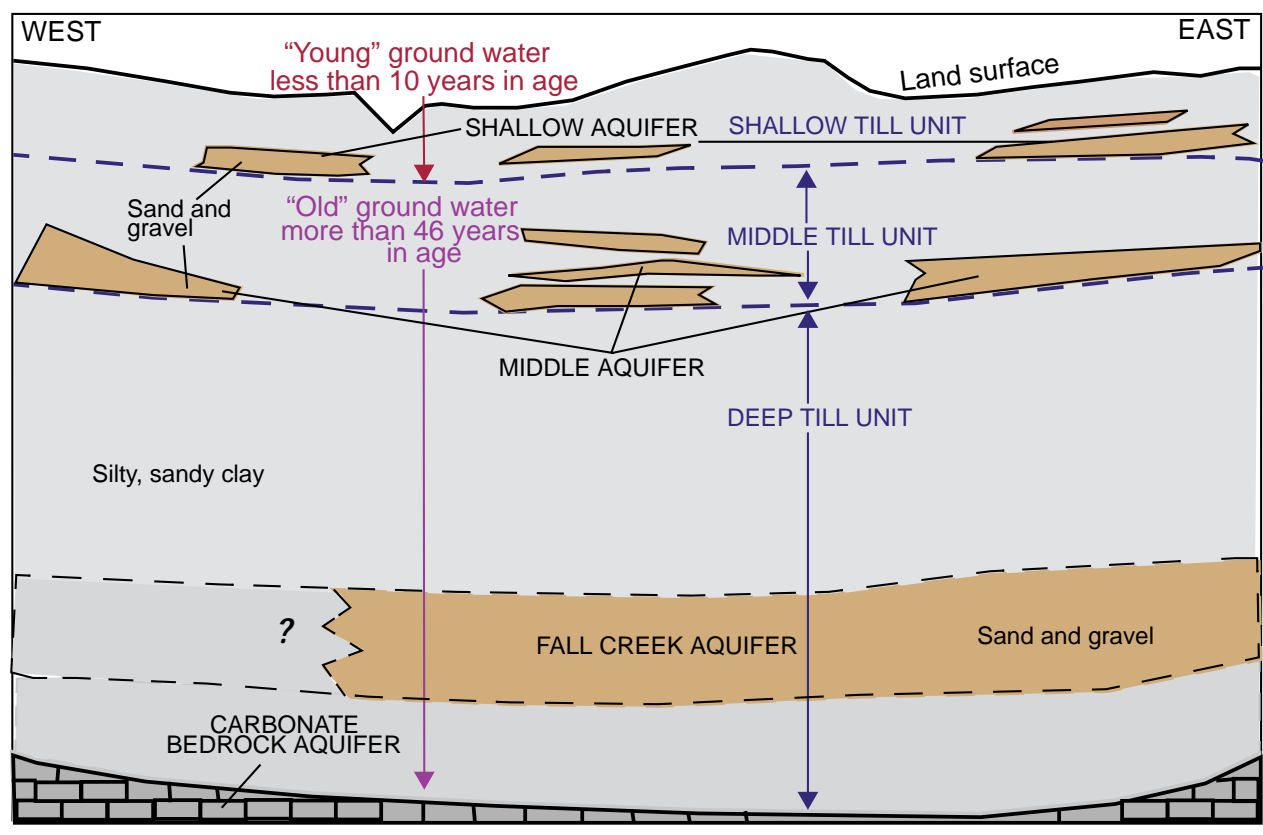

Figure 2. Generalized cross section showing conceptual model of the hydrogeology at the former Fort Benjamin Harrison, Marion County, Indiana.

northwest toward Fall Creek; this is the only area with sufficient data to map the horizontal-flow direction. Local flow directions in the shallow and middle till units near the two closed landfills were toward surface streams.

These water-level data also indicated the vertical flow of ground water was downward from the shallow aquifer to the middle aquifer and the Fall Creek aquifer.

\section{Ground-Water Age}

The date of recharge of the water in an aquifer is the year when the precipitation that replenished the aquifer became isolated from the atmosphere; groundwater age is determined by the date of recharge subtracted from the date when the environmental tracer for age was analyzed in a ground-water sample. Estimates of ground-water age can be used to assess the relative vulnerability of an aquifer to contamination from sources at or very near the land surface.

Tritium was used as the environmental tracer to estimate ground-water age. Tritium is the radioactive isotope of hydrogen with an atomic mass of three. Tritium in water can originate from natural radiation sources like cosmic rays and from manmade sources like nuclear-fusion bombs. Water molecules containing the tritium atom, substituted for the hydrogen atom, will follow the same path as water molecules with no tritium atoms. Therefore, tritium makes a good age tracer for recharge because it is unchanged by physical and biological processes underground.

Prior to 1952, tritium originating from natural cosmic rays was at a steady state in precipitation. When above-ground testing of nuclear-fusion bombs began in 1952, manmade tritium was introduced into the atmosphere and concentrations in precipitation peaked during 1963-64. Tritium concentrations in ground water can be used to detect if and when water was recharged after the nuclear-bomb testing enriched precipitation with tritium.

With qualitative interpretations of tritium concentrations, the following judgments were made about ground-water age (fig. 2). In the shallow aquifer in the eastern and central part of Fort Harrison, ground water is mostly "modern" and the water is less than 10 years old; in some places, the modern water is mixed with water that is as much as 46 years old. In the middle aquifer and the Fall Creek aquifer, ground water is more than 46 years old. On the basis of relative ground-water age, the shallow aquifer can be considered to be highly vulnerable to contamination from activities at the former Fort Harrison; the middle aquifer and the Fall Creek aquifer have a low vulnerability. -by Martin R. Risch

For more information, please contact:
District Chief
U.S. Geological Survey
5957 Lakeside Boulevard
Indianapolis, IN 46278
(317) 290-3333
Indiana District Home Page:
http://in.water.usgs.gov
USGS Home Page:
http://www.usgs.gov 